\title{
Investigating the Motivations of VC Syndication in China --- Do Chinese Leading VC Firms Make a Difference in Terms of Syndication Decisions
}

\author{
Yi $\operatorname{Tan}^{1} \&$ Xiaoli Wang ${ }^{2}$ \\ ${ }^{1}$ Antai Collge of Economics \& Management, Shanghai Jiaotong University, Shanghai, China \\ ${ }^{2}$ School of Management, Marist College, Poughkeepsie, NY, USA \\ Correspondence: Xiaoli Wang, School of Management, Marist College, Poughkeepsie, NY, USA. Tel: \\ 1-732-648-3326. E-mail: xiaoli.wang @ marist.edu
}

Received: March 3, 2016

Accepted: March 29, 2016

Online Published: May 25, 2016

doi:10.5539/ijef.v8n6p78

URL: http://dx.doi.org/10.5539/ijef.v8n6p78

\begin{abstract}
The venture capital industry in China is quickly evolving and becoming more and more important in the development of small and medium-size companies in China. Venture capital firms usually invest in young private transactions which are usually involved with high risk. In addition, the legal and political environments in China are significantly different from those in the developed markets and at the same time, China is undergoing significant changes of business environments, which brings even more challenges to the $\mathrm{VC}$ firms in China's market. Under these challenges, syndication has become a very popular investment method for the VC companies to diversify their investment risks. In this paper, we explore the various factors that might influence the motivation of VC firm's syndication decisions in China's market and especially focus on the impact of the firm's Chinese ownership. We believe that VC firms' Chinese ownership has a significant influence on the firm's decision for syndication investment and our empirical analysis confirms this. We find that Chinese VC firms have a significantly lower likelihood to make syndicated investment than their foreign counterparties. We also explore the interactions between the firms' Chinese ownership and other influencing factors to investigate their joint impacts on the syndication likelihood. We believe our study will provide a better and thorough understanding about the VC firms' syndication behavior in China's market and thus will offer significant values to Chinese policy makers in terms of their efforts to promoting VC development in China.
\end{abstract}

Keywords: venture capital, syndication, chinese ownership, logistic regression

\section{Introduction}

China's economy has grown significantly in recent years and the high rates of growth are expected to continue through 2025 (McKinsey \& Company, 2011). Small and medium sized enterprises (SMEs) are important participants in China's expanding economy, both as sources and beneficiaries of the expansion (Wang et al., 2011). At the same time, China's economic expansion also attracts a significant amount of venture capital investments which are important in providing capital and advisory \& managerial support to the selected SMEs. As a result, studying and investigating the investment behaviors of these VC firms will provide significant insights to further promote the growth in China's market.

It is commonly believed that since VC firms invest in relatively young private firms, it is usually involved with higher risk levels compared with other forms of business investing. In addition, China is undergoing significant changes of business environment, which brings even more challenges to VC firms in China. For example, Cumming (2007) and Cumming and MacIntosh (2003) argue that there are no generalized optimal contractual arrangements across china's markets due to the differences in laws, regulations and ways of conducting business etc. In their 2007 paper, Pukthuanthong and Walker (2007) also highlight these unique challenges faced by venture capital firms operating in China's legal, regulatory and cultural environment.

One of the common strategies for $\mathrm{VC}$ firms to manage the investment risks is to participate in syndicated transactions. For example, many researchers including Chemmanur et al. (2013), Mäkelä and Maula (2006, 2008), Meuleman and Wright (2011) etc, all document that cross-border venture capitalists tend to form syndication with local venture capital firms in order to reduce the agency problems and risks. Thus, an 
investigation of VC firms' syndication motivations and decisions will provide significant insights regarding the VC firms' investment behaviors. In this paper, we explore the various factors which are argued to have impacts on the VC firm's syndication motivations in China's market. Specifically, we investigate whether the Chinese ownership of the VC firms will play a different role in the firms' syndication decisions compared with VC firms from developed countries. We believe our study will provide a better and thorough understanding about the VC firms' syndication behaviors in China's market and thus will also offer meaningful insights to the local policy makers regarding their efforts in promoting the $\mathrm{VC}$ market development.

There have been a lot of researches on VC firms' syndication and most of them are about syndication behaviors in the developed markets (Lockett \& Wright, 1999, 2001; Brander et al., 2002; Manigart et al., 2002; Hopp \& Rieder, 2006; Deli \& Santhanakrishnan, 2010 etc).

Other papers, such as Fuller (2010), Tan et al. (2008), Du and Vertinsky (2008) focus on the VC firms in China's markets. For example, Du and Vertinsky (2008) examine the VC firms' risk mitigation strategies in China's market and they find that VC firms with little experiences are more likely to form syndication. They also demonstrate that $\mathrm{VC}$ firms are more likely to invest in the later stage of the business. Tan et al. (2015) systematically explore the various motivating factors of cross-border VC firms' syndication decision in China's market. They find that many factors include cultural distance, institutional learning capability, financing size, etc all impact the cross-border venture capitalists' syndication decisions in different ways.

However, none of the previous researches have specifically investigate whether the Chinese ownership plays a significant role in term of the VC firms' syndication motivation. In this paper, we extend the previous analysis by investigating whether the Chinese ownership will make a difference in terms of VC firms' syndication decision. We believe this is an interesting and important topic as there are significant differences between Chinese VC firms and foreign VC firms in terms of their organization structure, business structure, legal or government environment, etc and these differences are more likely to impact the firms' syndication decisions and investment behaviors as a result. Our research thus will provide a better understanding of the VC syndication behaviors in China's market and will offer significant inputs to local policy makers in terms of their efforts to further promoting the growth of the VC development in China.

The remainder of the paper is organized as follows. We first provide a literature review in section II, we then explain data and methodology in section III; empirical results are summarized in section IV and conclusions appear on section V.

\section{Literature Review}

Syndication is a popular investment strategy that VC firms adopt to reduce the investment risk. According to Lockett and Wright (2001): an equity syndicate involves several venture capitalists taking an equity stake in an investment. This investor group then need to make common decisions together and the payoffs are shared jointly among the participants as well (Wilson, 1968). Many previous researches (Sorenson \& Stuard, 2001; Tykvová \& Schertler, 2011 etc.) have documented many advantages for the VC firms to participate in syndicated investments instead of investments. These advantages include: information sharing, better screening and greater access to deal flow etc. Others, on the other hand, focus on the costs of syndication. For example, Eisenhardt (1989) postulates that agency costs can arise in situations involving two or more parties that are supposed to cooperate for a common goal. The agency costs are usually higher when the syndicate members have different risk tolerances and expectations, and the resolution of these differences may become more difficult as the number of syndicate members increases. Bygrave (1987) argue that in the case of VC syndication, VC firms may lose a competitive advantage by diluting the deal-related information to other investors. Wright and Lockett (2003) and Gerasymenko and Gottschalg (2008) etc claim that VC syndicate can also become a barrier to efficient decision making due to the slower decision-making processes; increased coordination costs and divergence of objectives among members etc. In another word, it can be more difficult and more time consuming within larger syndicates to renegotiate the investment agreements as well as to take actions when problems occur.

In addition, due to the unique business environment in China's VC market, we believe that the advantages and disadvantages of participating in syndicated financings in China may differ from those in the Western markets. For example, Pukthuanthong and Walker (2007) argue that the unique legal and institutional barriers and boundaries may lead to the differences in expectations and risk tolerances of VC firms in China and thus impact on their syndication decisions. At the same time, Chinese VC firms differ significantly from US and European VC firms in terms of their organization structure, business cultural etc, and these differences are expected to affect the firm's syndication decisions and behaviors as well. For instance, in U.S. and many European countries, 
limited partnership is the predominant ownership structure for VC firms. The funding of these limited partnerships usually comes from wealthy individuals, corporations, or institutional investors. In addition, the general or managing partners of these partnerships are usually the professional venture capitalists, whereas the investors are passive limited partners. This type of $\mathrm{VC}$ firm typically operates for a set number of years (usually about seven years with the potential to extend to a few more years) and then is terminated with original investment plus profits returned to the investors. Normally, a VC firm manages more than one fund; with one fund fully invested, one fund partially invested, and a third in the process of being raised.

On the other hand, the ownership structure of Chinese VC firms are quite different as government plays an important role in the development of VC market and thus significantly influences the business structure and strategies of Chinese VC firms. For instance, in 1984, the National Research Center of Science and Technology for Development advocated China to establish a venture capital system to promote high technology industries (White, Gao, \& Zhang, 2005). This advocacy has led to the establishments of many Chinese VC firms which are sponsored by China's central and local governments, as well as and government controlled universities. The existence of these state-owned VC firms is unique in China's VC market. In addition, Chinese VC firms more often come from banks or corporations, which are usually not the case in US or other European countries. Based on Mayer et al. (2005), VC firms whose investors are banks and pension funds tend to be more conservative and invest in the later phase of the project; while VC funds whose investors are individual investors prefer to invest in early stage, and are more willing to take risks. That being said, we argue that these different risk attitudes and different investment strategies between Chinese VC firms and foreign VC firms might have enormous impacts on their syndication behaviors.

Previous literatures have also explored various factors that might motivate the VC firms to form syndication. Most of the factors are usually coming from two major areas: project risks and VC firms' capability to manage these risks. These factors include but are not limited to: size of financing (Manigart et al. (2006)); investment in highly uncertain industries (Bygrave, 1987, 1988; Gottschalg \& Gerasymenko, 2008); the age of invested companies (Lockett et al., 2002); the size of VC firms (Bradford \& Bates, 2008; Verwaal et al., 2010); Depth and breadth of experience of the VC firms in the industry (De Clercq \& Dimov, 2006; DeClercq \& Dimov, 2008); VC firms ownership structure (Wang et al., 2002) etc.

In this paper, we extend the previous literature and investigate whether the Chinese ownership of the VC firms will make a significant difference in terms of their syndication decision. We hypothesize that the Chinese ownership not only impact on the firms' syndication decisions directly, but also interact with the above influencing factors and thus affect the firms' syndication decisions indirectly as well.

\section{Data and Methodology}

Our data are obtained from several sources including website www.ChinaVenture.com.cn, the Asian Venture Capital Journal Group, China Venture Capital Research Institute's "China Venture Capital Yearbook" (2003-2010), data published by China's National Bureau of Statistics as well as firms receiving VC financing etc. We also retrieve data from the venture capital firms' web sites (including but not are not limited to Lenovo, Intel, Softbank, IDG, Bain Capital, Sequoia China, CDH Investments, Northern Lights, Merchants China Direct Investments, Albatron, Up to the Morning and Heiner Asia). Our data cover the period from January 1993 to March 2010. For the purpose of being consistent, we limit our analysis to only first round financings. Our final sample includes $761 \mathrm{VC}$ investments coming from $194 \mathrm{VC}$ firms.

We then create various factors which are believed to have an impact on the firms' syndication decisions. These variables include:

\subsection{Size of Financing}

Manigart et al. (2006), in their 5-country study of 317 European VCs, find that risk sharing and portfolio diversification were more important to the VC firms' syndication decisions than selection and monitoring of deals. Participating in a syndication allows small and medium size VC firms to finance projects that they could not fully invest themselves. Based on this, we hypothesize that the size of financing will have a positive impact on the firms' syndication decisions, i.e. the larger the size of the financing, the more likely that the transaction will be syndicated. Variable "FinancingAmount", which is measured as the amount of money raised in the round, is then used to denote the size of the financing.

\subsection{High-Tech Industries}

We create a dummy variable "High_tech" to indicate the industry attributes of the investment. The variable equals 1 if the invested company belong to the high-tech industries and 0 otherwise. Per previous literatures, our 
classification of high-tech industries include information technology, telecommunications, computers, electronics, pharmaceuticals and environmental industries. These industries are usually believed to involve higher levels of information asymmetry and uncertainty and thus are more likely to motivate the VC firms to form syndication. We hypothesize that the firm will be more likely to form syndication if the investment is in the high-tech industries.

\subsection{Age of the Invested Companies}

Low survival rate of startup companies is widely observed around the world. Although VC firms can get favorable share prices when investing in these startup young companies, they are subject to significant risks which may render them huge losses in the future. Syndication, however, with risks shared among syndication partners, can significantly dilute and reduce the investment risks associated with these young companies. Accordingly, we construct a variable "Investeeage" to represent the invested companies' age and we hypothesize that it will have a negative relationship with the VC firms syndication decisions, i.e. the smaller the invested company's age, the more likely the VC firms will form syndication in the investment.

\subsection{Size of VC Firm}

The size of the VC firms is expected to correlate with the VC firms' syndication decisions positively. As the size of the VC firm increases, the VC firm has more capability to finance a given project while maintaining risk diversification. Larger VC firms also have more managerial and advisory personnel to assist project development and thus are less likely in need of forming syndication for risk diversification and management support (Bates \& Bradford, 2008). In addition, it is believed that larger-size VC firms may have more access to good deals which also motivate them to invest solely instead through syndication (Bates \& Bradford, 2008; Verwaal et al., 2010). Variable "AUM", the total capital managed by the VC firms, is then created to represent the size of the VC firms.

\subsection{Depth of Experience in Firm's Industry}

We use the number of investment cases in the same industry as a proxy for the VC firm's depth of experience in the industry and variable "Industryinv" is created accordingly. We argue that investing in an unfamiliar industry usually involve higher risks for the VC firms due to the lack of knowledge in that particular industry given the industry's issues and challenges (De Clercq \& Dimov, 2006; DeClercq \& Dimov, 2008). Although some working knowledge (like constructing contracts, providing subsequent capital and exit planning) can be transferred between industries, a major part of successful VC financing comes from understanding the key issues and challenges of firms in the industry in which the investment takes place. Syndication is an effective way to solve the uncertainty problems. VC firms can use the knowledge of syndicate members to offset their lack of knowledges. As a result, we hypothesize that the number of investments in the same industry will have a negative relationship with syndication, i.e., the fewer the previous investments in the firm's industry by VC firms, the more likely that the financing is syndicated.

\subsection{Breadth of Industry Experience in China}

Besides to the depth of the experience, the breadth of the VC firms' experience will also have an impact on the firms' syndication decisions. We use the number of industries that the VC firms have already invested in China as an approximation of the firm's breath of experiences, which is denoted by the variable "Industrexp" We argue that the number of industries in which the VC firms have investment experiences in China can indicate the firms' general familiarity with the management issues in China. The wider the set of China's industries in which the VC firms have been involved, the less the VC firms' need for access to other VC firm's knowledge through syndication, i.e. there is a negative relationship between variable "Industryexp" and firms' syndication likelihood.

\subsection{Length of Time Operating in China}

Prior operating experience can improve the VC firm's capability to deal with undesirable conditions and thus motivate the VC firm to invest independently. In addition, with the growth of firm's investment experience, the firm's capability to accurately evaluate and efficiently manage a project can also be greatly improved. We create a variable "Chinaexp" to measure the length of time that a VC firm has been operating in China and we hypothesize that it will correlated with the firm's syndication decision negatively.

\subsection{Syndication Experience}

We argue that VC firms' previous syndication experience will also have an impact on the firms' future syndication decisions. We create a variable "Syndicationexp", which is measured as the number of syndicated investment that the firm have done before and use it as a proxy for the firms' previous syndication experience. 


\subsection{Independent/Affiliate Ownership}

The ownership structure of the VC firms can be categorized as either independent or affiliated. An independent VC firm is owned by shareholders who are ordinary investors, such as institutional investors and wealthy individuals; while an affiliated $\mathrm{VC}$ firm is a subsidiary of an existing business. It is usually believed that independent VC firms have more freedom to select investment strategy while affiliated VC firms' investment strategies are more often restricted to meet the circumstances and goals of the parent organization. Wang et al. (2002) study the independent v.s. affiliated VC firms in Singapore and find that these two different types of VC firms have different investment traits: independent VC firms are more likely to form syndications than the affiliated VC firms. They argue that this is due to the fact that independent VC firms use syndication to spread out the risks of their investments, while affiliated $\mathrm{VC}$ firms tend to invest with a later stage project due to the parent firm's strategic restriction and thus have less motivation to form syndications. Following them, we also create a dummy variable "Indepdummy" to represent the VC firm's ownership. The variable will equal to 1 for the independent structure and 0 otherwise. We hypothesize that the variable "Indepdummy" will have a positive relationship with the firms' syndication decisions.

\subsection{Chinese Dummy Variable}

Last but the least, we create is a dummy variable "China" to represent the VC firms' Chinese ownership. The variable equals 1 if it is leading syndication partner has a Chinese ownership and 0 otherwise. As we explained before, we believe that Chinese ownership has a significant impact on the firm's syndication decision and a main purpose of this paper is to investigate its impact on the determination of syndication.

We then create interactive variables between Chinese dummy variable and other factor variables. These interactive variables enable us to evaluate the indirect impacts of Chinese ownership on the firms' syndicate decisions through its joint relationship with other influencing factors. The detailed definitions of the variables are summaized in table 1 .

Table 1. Variable definitions

\begin{tabular}{|c|c|}
\hline Variable Name & Definition \\
\hline Syndication & $\begin{array}{l}\text { Dummy variable, which equals } 1 \text { for Syndicated investment and } 0 \text { otherwise. Projects with } \mathrm{n} \text { investors } \\
\text { become n observations; each record corresponds to one investor }\end{array}$ \\
\hline FinaningAmount & $\begin{array}{l}\text { The amount of money raised in this round. The variable is used to represent the size of the financing. The } \\
\text { unit is million US dollar. }\end{array}$ \\
\hline AUM & $\begin{array}{l}\text { Total capital managed by the VC firm and the variable is used to denote the size the VC firms. The unit is } \\
\text { million US dollar. }\end{array}$ \\
\hline High_tech & $\begin{array}{l}\text { Dummy variable, which equals } 1 \text { if the invested companies are in the high tech industries, including: } \\
\text { Information technology, telecommunications, computers, electronics, pharmaceuticals and environmental, } \\
\text { and } 0 \text { otherwise }\end{array}$ \\
\hline Investeeage & Age of the invested company \\
\hline Industryinv & $\begin{array}{l}\text { Before investing in this project, how many times the VC firms have invested in this industry in Chin. The } \\
\text { variable is used to measure the depth of the VC firms' experience. }\end{array}$ \\
\hline Chinaexp & Number of years from the VC firms' first investment in China to this project. \\
\hline Industrexp & $\begin{array}{l}\text { Before this project, the total number of industries in China in which the VC firms have invested. The } \\
\text { variable is used to measure the broadness of the VC firms' experiences. }\end{array}$ \\
\hline Syndicationexp & The number of syndicated investments the VC firms have invested before \\
\hline Indep & $\begin{array}{l}\text { Dummy variable, which equals } 1 \text { if the } \mathrm{VC} \text { firm is an independent organization and } 0 \text { if the firms is } \\
\text { affiliated. }\end{array}$ \\
\hline China & Dummy variable, which equals 1 for Chinese VC firm and 0 for foreign ones \\
\hline CFinaningAmount & Interactive variable FinancingAmount*China \\
\hline CAUM & Interactive variable $\mathrm{AUM}^{*}$ China \\
\hline CHigh_tech & Interactive variable High_tech*China \\
\hline CInvesteeage & Interactive variable Investeeage ${ }^{*}$ China \\
\hline CIndustryinv & Interactive variable Industryinv* ${ }^{*}$ China \\
\hline Chinaexp & Interactive variable Chinaexp*China \\
\hline CIndustryexp & Interactive variable Industryexp*China \\
\hline CSyndicationexp & Interactive variable Syndicationexp*China \\
\hline CIndep & Interactive variable Syndicationexp*China \\
\hline
\end{tabular}


Table 1 summarize the variables and their definitions in our analysis.

A logit regression is then performed on the factor variables, China dummy variable and the interactive variables to investigate the impact of Chinese ownership on the firms' syndication decisions.

\section{Empirical Results}

In this section, we present our empirical results. We first examine the summary statistics of our variables and the result is summarized in Table 2. From table 2, we noticed the following: first, there are big variations of in terms of the size of the investment as well as the size of the VC firm. For example, we see that the variable FinancingAmount ranges from 0.03 million US dollar to 1575 million US dollar with a standard deviation of 123.390 million US dollar. This implies that our data covers a big range of the investment sizes and therefore have little or no size biases. We also observed from the table that the average age of the invested companies are 6.9 years and the $\mathrm{VC}$ firms have an average experience of 4.7 years in terms of their investment in China (Chinaexp).

Table 2. Summary statistics of the variables

\begin{tabular}{lccccc}
\hline & Min & Max & Median & Mean & Standard Deviation \\
\hline Syndication & 0 & 1 & 1 & 0.639 & 0.481 \\
FinaningAmount & 0.03 & 1575 & 10 & 36.980 & 123.390 \\
AUM & 5 & 200000 & 417.2 & 2517.700 & 10415.440 \\
Industryinv & 0 & 55 & 0 & 2.017 & 4.996 \\
high_tech & 0 & 1 & 1 & 0.518 & 0.500 \\
Investeeage & 0 & 93 & 5 & 6.957 & 8.547 \\
Chinaexp & 0 & 16 & 4 & 4.725 & 3.747 \\
industryexp & 0 & 16 & 3 & 4.130 & 3.839 \\
synidcationexp & 0 & 102 & 0 & 5.059 & 11.167 \\
indep & 0 & 1 & 1 & 0.631 & 0.483 \\
China & 0 & 1 & 0 & 0.343 & 0.475 \\
\hline
\end{tabular}

Table 2 shows the summary statistics of the variables, including median, mean, standard deviation, minimum and maximum. For variable FinancingAmount and AUM the unit is million US dollar.

We then investigate the pearson correlation and Variance Inflation Factor (VIF) among our variables to see whether there are any potential multicollinearity problems. The correlation coefficient matrix in table 3 indicate that all correlation coefficients between variables are below 0.5 except the correlation between syndicationexp and industryexp, which is just marginally above 0.5 . This implies that the VC firms who have more investment experiences in the industry also tend to have more syndication experiences. The VIF value presented in table 4 show that none of the VIF values is above 2.5 , which implies that multicollinearity is not a problem with the logit regression models that we report below (researchers usually get concerned when VIF value is above 2.5 . This implies that the variable has a $\mathrm{R}^{2}$ of 0.60 with other variables, which usually indicates a multicollinearity problem)

Table 3. Pearson correlation among the variables

\begin{tabular}{|c|c|c|c|c|c|c|c|c|c|c|}
\hline & Syndication & FinaningAmount & Industryinv & high_tech & Investeeage & Chinaexp & industryexp & synidcationexp & indep & China \\
\hline Syndication & 1 & & & & & & & & & \\
\hline $\begin{array}{l}\text { FinaningAmo } \\
\text { unt }\end{array}$ & 0.045 & 1 & & & & & & & & \\
\hline AUM & 0.025 & 0.138 & & & & & & & & \\
\hline Industryinv & -0.034 & -0.043 & 1 & & & & & & & \\
\hline high_tech & 0.079 & -0.128 & 0.199 & 1 & & & & & & \\
\hline Investeeage & -0.084 & 0.204 & -0.022 & -0.269 & 1 & & & & & \\
\hline Chinaexp & -0.184 & 0.059 & 0.442 & -0.058 & 0.129 & 1 & & & & \\
\hline industryexp & -0.102 & 0.043 & 0.108 & -0.311 & 0.135 & 0.39 & 1 & & & \\
\hline synidcationexp & 0.341 & -0.013 & 0.503 & -0.022 & -0.019 & 0.407 & 0.295 & 1 & & \\
\hline indep & 0.003 & 0.065 & 0.186 & 0.019 & -0.035 & 0.153 & 0.204 & 0.187 & 1 & \\
\hline China & -0.131 & -0.063 & -0.07 & -0.051 & 0.101 & -0.098 & 0.04 & -0.103 & -0.382 & 1 \\
\hline
\end{tabular}


Table 3 shows the Pearson Correlation metrics among our variables.

Table 4. The VIF (Variance Inflation Factor) of the variables

\begin{tabular}{cc}
\hline Variables & VIF \\
\hline FinaningAmount & 1.649 \\
AUM & 1.049 \\
Industryinv & 1.041 \\
high_tech & 1.148 \\
Investeeage & 1.614 \\
Chinaexp & 1.296 \\
industryexp & 1.182 \\
synidcationexp & 1 \\
indep & 1.287 \\
China & 1.255 \\
\hline
\end{tabular}

Table 4 shows the VIF (Variance Inflation Factor) of our variables.

We then use the two sample $t$ test to investigate the non-linear impacts of our various factors on the VC firms' syndication decisions. We first classify our samples into two groups based on the various factors. For continuous variables, such as FinancingAmount, SUM, Investeeage, etc, we use the sample mean value as a threshold. Group 1 are the VC firms which have a variable level that is smaller than the mean value; while Group 2 includes the firms with a higher variable value above the mean. For binary variables, such as Indep and China, Group1 includes the firms whose value equals 0 ; while firms with a value equals 1 belong to the Group 2 . Table 5 shows the two sample $t$ test result regarding the mean level of Syndication between these two groups.

Table 5. Two sample T test about mean value of syndication based on various variables

\begin{tabular}{cccccc}
\hline \multicolumn{7}{c}{ Mean of Syndication For the Groups } \\
& $\begin{array}{c}\text { G1: factor variable }=0 \text { or } \\
\text { factor variable }<=\text { mean }\end{array}$ & $\begin{array}{c}\text { G 2:factor variable }=1 \text { or } \\
\text { factor variable }>\text { mean }\end{array}$ & $\begin{array}{c}\text { Difference of mean } \\
\text { syndication (G1-G2) }\end{array}$ & T statistics & P Value \\
\hline FinaningAmount & 0.633 & 0.669 & -0.037 & 0.789 & 0.431 \\
AUM & 0.638 & 0.647 & -0.009 & 0.171 & 0.864 \\
Industryinv & 0.643 & 0.623 & 0.019 & 0.437 & 0.662 \\
high_tech & 0.599 & 0.675 & -0.076 & -2.172 & $0.030^{*}$ \\
Investeeage & 0.680 & 0.573 & 0.107 & -2.978 & $0.003 * *$ \\
Chinaexp & 0.707 & 0.564 & 0.143 & -4.131 & $0.000^{* * *}$ \\
industryexp & 0.661 & 0.601 & 0.060 & -1.662 & 0.097. \\
synidcationexp & 0.532 & 1.000 & -0.468 & 22.727 & $0.000^{* * *}$ \\
indep & 0.637 & 0.640 & -0.003 & 0.071 & 0.943 \\
China & 0.684 & 0.552 & 0.132 & 3.555 & $0.000^{* * *}$ \\
\hline
\end{tabular}

This table shows the two sample $t$ test of the syndication variable between the two groups classified based on our different factors. The first group (G1) include the cases whose variable value is either 0 or smaller than the sample mean while the second group (G2) include the cases in which the variable value is 1 or above the sample mean. ***, **, *, and . indicate significance at $0.001,0.01,0.5$, and 0.1 , respectively.

From Table 5, we see clearly that VC firms with Chinese ownership have significantly less syndication cases than their foreign peers. The mean level of syndication for the Chinese group is 0.552 vs the mean level for the foreign group at 0.684 and difference is significant at $1 \%$ level. We also see that variable high_tech, investeeage, Chinaexp, industryexp and syndicationexp have significantly different mean levels of syndication between the two groups. To illustrate, as we expect, the VC firms who invest in the high_tech industries, and who have more previous syndication experiences tend to have a higher level of syndication cases than their peers. On the other hand, the VC firms who have more investment experiences in china, and more investment experience in the industry have significantly less syndication cases than their counter parties. We also see that firms with higher asset levels under management and invest in larger deals tend to have more syndication cases than their counter peers, but the differences are not significantly different.

Last but not least, a logistic regression is conducted to investigate the linear impact of our various factors on the 
determination of VC firm's syndication decision. We first run the logistic regression without interactive variables and result is shown on Table 6.

Table 6. Logistic regression of syndication on explanatory factors excluding interactive factors with China dummy

\begin{tabular}{lllll}
\hline & Estimate & Std. Error & $\mathrm{z}$ value & $\operatorname{Pr}(>|\mathrm{z}|)$ \\
\hline (Intercept) & $1.55 \mathrm{E}+00$ & $4.09 \mathrm{E}-01$ & 3.794 & $0.000 * * *$ \\
FinaningAmount & $4.07 \mathrm{E}-03$ & $1.30 \mathrm{E}-03$ & 3.124 & $0.002 * *$ \\
AUM & $9.05 \mathrm{E}-06$ & $2.45 \mathrm{E}-05$ & 0.369 & 0.712 \\
Industryinv & $-9.87 \mathrm{E}-01$ & $4.41 \mathrm{E}-01$ & -2.241 & $0.025 *$ \\
high_tech & $5.30 \mathrm{E}-01$ & $3.41 \mathrm{E}-01$ & 1.554 & 0.120 \\
Investeeage & $-3.73 \mathrm{E}-03$ & $2.13 \mathrm{E}-02$ & -0.175 & 0.861 \\
Chinaexp & $-5.44 \mathrm{E}-01$ & $8.47 \mathrm{E}-02$ & -6.42 & $0.000 * * *$ \\
industryexp & $-2.24 \mathrm{E}-01$ & $7.42 \mathrm{E}-02$ & -3.012 & $0.003 * *$ \\
synidcationexp & $2.55 \mathrm{E}+01$ & $1.00 \mathrm{E}+03$ & 0.026 & 0.979 \\
indep & $-6.52 \mathrm{E}-01$ & $3.60 \mathrm{E}-01$ & -1.814 & 0.070. \\
China & $-8.65 \mathrm{E}-01$ & $3.69 \mathrm{E}-01$ & -2.347 & $0.019 *$ \\
\hline
\end{tabular}

This table shows the logistic regression results of syndication on variaous explantory factors. $* * *, * *, *$, and indicate significance at 0.001 , $0.01,0.5$, and 0.1 , respectively.

From Table 6, we see that the factors which significantly impact the syndication likelihood include: FinancingAmount, Industryinv, industryexp, Chinaexp, industryexp, indep and China and they all have signs as we expected. For example, we see that FinancingAmount has a positive coefficient significant at $1 \%$ level. This implies that the larger financing amount of the deals are associated with a higher likelihood of the syndication. The negative coefficient of the variable Industryinv (significant at 5\% level) suggests that VC firms who have more depth of experience in the same industry (number of investments in the same industry) are less likely to form syndication. Meanwhile, the firms which have more breadth of the industry experience (variable industryexp, which is calculated as the number of industries the firms have invested in China) are also more likely to invest independently (negative coefficient, significant at 1\%). Variable Chinaexp also has a negative coefficient, which is significant at $0.1 \%$. This suggests that the more operating experiences the VC firms have in China, the less likely they will form syndication for the investment. The negative coefficient of variable indep (significant at 10\%) suggests that independent VC firms are less likely to form syndication than affiliated VC firms. Last but not least, we see that the dummy variable China has a significantly negative coefficient. This confirms our previous hypothesis that Chinese ownership of the VC firms will significantly influence the motivation of the firm's syndication decision, i.e., reduce the likelihood that the firm will form syndication in the investment. We argue that one possible reason for foreign VC firms to prefer syndication investment is that they want to cooperate with local partners to enhance the legal, social or other resourceful relationship with businesses in China. In another words, as Tan et al. (2015) point out, one of the useful benefits of syndication is to help cross-border VC firms to solve the outsider disadvantage problem when they investment in an unfamiliar investment environment in China.

We also see from Table 6 that although the coefficients of other variables are not significant, they are of the signs as we expected. For example, we see that the variable High_tech has a positive coefficient, suggesting that firms which invest in the high-tech industries tend to have a higher likelihood to form syndication. This is consistent with our hypothesis as we believe that these firms use syndication to diversify the risks involved in the high-tech industries. We also see the coefficients for the variable investeeage and syndicaitonexp are both negative while coefficient for syndicaitonexp is positive. This implies that firm's which have more previous syndication experiences are more likely to do syndicated investment again and the maturity of the investee companies reduce the motivation of the firm to form syndication. The coefficient of variable AUM is also positive, suggesting that larger VC firms are more likely to form syndication than smaller firms. We believe that this is due to the fact that larger VC firms typically set upper limits for investment in a single firm to prevent managers from committing the VC firm to an exorbitant amount of unsystematic risk. As a result, larger VC firms are more likely to form syndication to diversify the risk involved with a single investment.

We then add the interactive factors as explanatory variables and rerun the logistic regression analysis. The result is shown on Table 7. 
Table 7. Logistic regression of syndication on factors including interactive factors with China dummy

\begin{tabular}{lllll}
\hline & Estimate & Std. Error & z value & $\operatorname{Pr}(>|\mathrm{z}|)$ \\
\hline Intercept) & $2.04 \mathrm{E}+00$ & $5.49 \mathrm{E}-01$ & 3.72 & $0.000 * * *$ \\
FinaningAmount & $5.23 \mathrm{E}-03$ & $1.48 \mathrm{E}-03$ & 3.544 & $0.000 * * *$ \\
AUM & $1.80 \mathrm{E}-05$ & $2.07 \mathrm{E}-05$ & 0.869 & 0.384 \\
Industryinv & $-9.15 \mathrm{E}-01$ & $6.00 \mathrm{E}-01$ & -1.524 & 0.127 \\
high_tech & $5.90 \mathrm{E}-01$ & $4.57 \mathrm{E}-01$ & 1.292 & 0.196 \\
Investeeage & $-2.31 \mathrm{E}-02$ & $2.80 \mathrm{E}-02$ & -0.822 & 0.411 \\
Chinaexp & $-5.38 \mathrm{E}-01$ & $1.08 \mathrm{E}-01$ & -4.965 & $0.000 * * *$ \\
industryexp & $-4.28 \mathrm{E}-01$ & $1.21 \mathrm{E}-01$ & -3.529 & $0.000 * * *$ \\
synidcationexp & $2.55 \mathrm{E}+01$ & $1.08 \mathrm{E}+03$ & 0.024 & 0.981 \\
indep & $-8.67 \mathrm{E}-01$ & $4.74 \mathrm{E}-01$ & -1.829 & 0.067. \\
China & $-1.32 \mathrm{E}+00$ & $8.10 \mathrm{E}-01$ & -1.633 & 0.102 \\
CFinancing & $-1.53 \mathrm{E}-02$ & $1.33 \mathrm{E}-02$ & -1.148 & 0.251 \\
CAUM & $-8.65 \mathrm{E}-04$ & $8.22 \mathrm{E}-04$ & -1.052 & 0.292 \\
CIndustryinv & $1.29 \mathrm{E}-02$ & $9.42 \mathrm{E}-01$ & 0.014 & 0.989 \\
Chigh_tech & $-3.78 \mathrm{E}-01$ & $7.30 \mathrm{E}-01$ & -0.518 & 0.605 \\
CInvesteeage & $1.59 \mathrm{E}-02$ & $4.33 \mathrm{E}-02$ & 0.366 & 0.714 \\
CChinaexp & $-7.42 \mathrm{E}-02$ & $1.92 \mathrm{E}-01$ & -0.386 & 0.700 \\
Cindustryexp & $4.42 \mathrm{E}-01$ & $1.55 \mathrm{E}-01$ & 2.859 & $0.004 * *$ \\
Csyndicationexp & $7.00 \mathrm{E}+01$ & $1.35 \mathrm{E}+03$ & 0.052 & 0.959 \\
Cindep & $6.55 \mathrm{E}-01$ & $7.69 \mathrm{E}-01$ & 0.852 & 0.394 \\
\hline
\end{tabular}

This table shows the logistics regression results of syndication varaible on the various explanatory variables as well as the interactive varaibles between explantory factors and the China dummy varaible. ***,**, *, and indicate significance at $0.001,0.01,0.5$, and 0.1 , respectively.

When we add the interactive factors to the logistic regression, the story is slightly different. Variable FinancingAmount, Chinaexp, industryexp, indep remain significant with the expected signs; variable Industryinv keeps the expected sign (negative) but loses the significance. Dummy variable China has the same story: the sign remains negative, implying that the Chinese ownership of the VC firms will reduce the likelihood of their syndication decisions, but the impact is not significant.

Among all the interactive variables, we see only variable Cindustryexp is significant at $1 \%$, but the sign is positive. This means that despite the overall negative impacts of Chinese ownership (variable China) and Industryexp on the likelihood of syndication, when these two variables are combined together, it actually significantly increase the likelihood of syndication. That also implies that foreign VC firms which have broader investment experience (larger industryexp) are more likely to invest independently while Chinese VC firms with more investment experiences are more likely to invest in syndication. We argue that this might be due to the strategic alliance which the Chinese VC firms need to form in their VC investment. We also notice that although not significant, the coefficients of interactive variables Cindustryinv, Cinvesteeage and Csyndicaitonexp, Cindep are positive, which implies that Chinese VC firms who have more industry experience (industryinv) or invest in more mature companies (investeeage) or have more previous syndication experience (syndicationexp), or are independent VC firms (indep), are more likely to invest in syndication than foreign VC firms. On the other hand, the negative coefficients of interactive variables CFinancing, CAUM, Chigh_tech and CChinaexp imply that Chinese VC firms which have a larger asset under management (AUM), or invest in a larger deal (FinancingAmount) or have more experience in China (Chinaexp) are less likely to invest in syndication than foreign VC firms.

\section{Conclusions}

The venture capital industry in China is quickly evolving and is becoming more and more important in the development of small and medium size companies in China. Since venture capital firms usually invest in young private transactions, their investment usually involve much higher risks. In addition, the legal and political environments in China are significantly different from those in the developed markets. At the same time, China is undergoing significant changes of business environments, which brings even more challenges to $\mathrm{VC}$ firms in China's market. In order to diversify their investments, syndication investment has become a very popular investment method for the $\mathrm{VC}$ companies. In this paper, we explore the various factors that might influence the motivation of VC firms' syndication decisions in China's market and especially focus on the firms' Chinese 
ownership. We believe that VC firms' Chinese ownership has a significant impact on the firm's decision for syndication investment and our empirical analysis confirms this. We find that Chinese VC firms have a significantly lower likelihood to do syndicated investment than their foreign counterparties. We also explore the interactions between the firms' Chinese ownership and other influencing factors to investigate their joint impacts on the syndication likelihood. We find that the firms' Chinese ownership interact closely with the firms' broader investment experience in terms of their joint impacts on the firms' syndication decisions: i.e. foreign $\mathrm{VC}$ firms which have broader investment experience are more likely to invest independently while Chinese VC firms with more investment experiences are more likely to invest in syndication. We argue that this might be due to the strategic alliance the Chinese VC firms need to form in their VC investment.

We believe our study will provide a better and thorough understanding about the VC firms' syndication behavior in China's market and thus will offer significant inputs to Chinese policy makers in terms of their efforts to promoting VC development in China.

\section{Acknowledgments}

The authors thank for the support of National Natural Science Foundation of China (71173146,71573174).

\section{References}

Betaes, T., \& William, B. (2008). Venture Capital Investment In Minority Business. Journal of Money, Credit and Banking, 4(2-3), 489-504. http://dx.doi.org/10.1111/j.1538-4616.2008.00123.x

Brander, J. A., Raphael, A., \& Werner, A. (2002). Venture-Capital Syndication: Improved Venture Selection vs. the Value-Added Hypothesis. Journal of Economics and Management Strategy, 11(3), 422-451. http://dx.doi.org/10.1162/105864002320272558

Bygrave, W. D. (1987). Syndicated investments by venture capital firms: A networking perspective. Journal of Business Venturing, 2, 139-154. http://dx.doi.org/10.1016/0883-9026(87)90004-8

Bygrave, W. D. (1988). The structure of networks in the venture capital industry. Journal of Business Venturing, 3, 137-157. http://dx.doi.org/10.1016/0883-9026(88)90023-7

Cumming, D. (2007), United States venture capital contracting: Foreign securities. Advances in Financial Economics, 12, 405-444. http://dx.doi.org/10.1016/S1569-3732(07)12016-8

Cumming, D. J. (2006). The determinants of venture capital portfolio size: Empirical Evidence. Journal of Business, 79(3), 1083-1126. http://dx.doi.org/10.1086/500670

Cumming, D., \& MacIntosh, J. G. (2003). Venture capital exits in Canada and the United States. University of Toronto Law Journal, 53, 101-200. http://dx.doi.org/10.2307/3650880

De Clercq, D., \& Dimov, D. (2006). Venture capital investment strategy and portfolio failure rate: A longitudinal $\begin{array}{lllll}\text { study. } & \text { Entrepreneurship } \quad \text { Theory }\end{array}$ http://dx.doi.org/10.1111/j.1540-6520.2006.00118.x

De Clercq, D., \& Dimov, D. (2008). Internal knowledge development and external knowledge access in venture capital investment performance. Journal of Management Studies, 45(3), 585-612. http://dx.doi.org/10.1111/j.1467-6486.2007.00747.x

Deli, D., \& Santhanakrishnan, M. (2010). Syndication in Venture Capital Financing. Financial Review, 45, 557-578. http://dx.doi.org/10.1111/j.1540-6288.2010.00261.x

Eisenhardt, K. (1989). Building Theories from Case Study Research. The Academy of Management Review, 14(4), 532-550.

Eisenhardt, K. M., \& Claudia, B. S. (1996). Resource-based View of Strategic Alliance Formation: Strategic and Social Explanations in Entrepreneurial Firms. Organization Science, 7(2), 136-150. http://dx.doi.org/10.1287/orsc.7.2.136

Fuller, D. B. (2010). How Law, Politics and Transnational Networks Affect Technology Entrepreneurship: Explaining Divergent Venture Capital Investing Strategies in China. Asia Pacific Journal of Management, 27, 445-459. http://dx.doi.org/10.1007/s10490-009-9149-0

Gerasymenko, V., \& Gottschalg, O. (2008). Antecedents and Consequence of Venture Capital Syndication (Summary). Frontiers of Entrepreneurship Research, 28(3).

Hopp, C., \& Rieder, F. (2006). What drive venture capital syndication? Working paper, University of Konstanz.

Lockett, A., \& Wright, M. (1999). The syndication of private equity: Evidence from the UK. Venture Capital, 1, 
303-324. http://dx.doi.org/10.1080/136910699295839

Lockett, A., \& Wright, M. (2001). The syndication of venture capital investments. Omega, 29, 375-390. http://dx.doi.org/10.1016/S0305-0483(01)00024-X

Lockett, A., Murray, G., \& Wright, M. (2002). Do UK venture capitalists still have a bias against investments in new, technology-based firms. Research Policy, 31(6), 1009-1030. http://dx.doi.org/10.1016/S0048-7333(01)00174-3

Manigart, S., Andy, L., Miguel, M., Mike, W., Hans, L., Hans, B., Philippe, D., \& Ulrich, H. (2006). Venture Capitalists' Decision to Syndicate. Entrepreneurship Theory and Practice, 30(2), 131-153. http://dx.doi.org/10.1111/j.1540-6520.2006.00115.x

Manigart, S., Lockett, A., Meuleman, M., Wright, M., Landstrom, H., Bruining, H., Desbrieres, P., \& Hommel, U. (2002). Why do European venture capital companies syndicate? Working paper, SSRN.

Mayer, C., Schoors, K., \& Yafeh, Y. (2005). Sources of funds and investment activities of venture capital funds: Evidence from Germany, Israel, Japan and the United Kingdom. Journal of Corporate Finance, 11(3), 586-608. http://dx.doi.org/10.1016/j.jcorpfin.2004.02.003

McKinsey, \& Company. (2011). McKinsey Global Survey Results Economic Conditions Snapshot. McKinsey Quarterly, March.

Pukthuanthong, K., \& Walker, T. (2007). Venture capital in China: A culture shock for Western investors. Management Decision, 45, 708-731. http://dx.doi.org/10.1108/00251740710745999

Qiangian, D., \& Ilan, B. V. (2008). Risk mitigation strategies of foreign venture capitalists in China. SSRN Working Paper.

Sorenson, O., \& Toby, E. S. (2001). Syndication Networks and the Spatial Distribution of Venture Capital Investments. American Journal of Sociology, 106, 1546-1588. http://dx.doi.org/10.1086/321301

Tan, J., Wei, Z., \& Jun, X. (2008). Managing Risk in a Transitional Environment: An Exploratory Study of Control and Incentive Mechanisms of Venture Capital Firms in China. Journal of Small Business Management, 46, 263-285. http://dx.doi.org/10.1111/j.1540-627X.2008.00243.x

Tan, Y., Xiaoli, W., \& Linlu, T. (2015). Institutional learning, Cultural differences and the Motivation of Syndication among Cross-boards Venture Capital Firms. Working paper.

Tykvová, T., \& Schertler, A. (2011). Cross-border venture capital flows and local ties: Evidence from developed countries. Quarterly Review of Economics and Finance, 51, 36-48. http://dx.doi.org/10.1016/j.qref.2010.09.005

Verwaal, E., Bruining, H., Wright, M., Manigart, S., \& Lockett, A. (2010). Resources access needs and capabilities as mediators of the relationship between VC firm size and syndication. Small Business Economics, 34, 277-291. http://dx.doi.org/10.1007/s11187-008-9126-x

Wang, K., Clement, K. W., \& Qing, L. (2002). Differences in performance of independent and finance-affiliated venture capital firms. Journal of Financial Research, 25, 59-80. http://dx.doi.org/10.1111/1475-6803.00004

Wang, Y., Xu, J., \& Yip, A. (2011). Financial Services Practice: China's Changing Wholesale Landscape. McKinsey Quarterly, March, 1-7.

White, S., Gao, J., \& Zhang, W. (2005). Financing New Ventures in China: System Antecedents and Institutionalization. Research Policy, 34, 894-913. http://dx.doi.org/10.1016/j.respol.2005.04.002

Wilson, R. (1968). The Theory of Syndicates. Econometrica, 36, 119-132. http://dx.doi.org/10.2307/1909607

Wright, M., \& Andy, L. (2003). The Structure and Management of Alliances: Syndication in the Venture Capital $\begin{array}{lllll}\text { Industry. } & \text { Journal } & \text { Studies, } & 40, & \text { Management }\end{array}$ http://dx.doi.org/10.1046/j.1467-6486.2003.00412.x

\section{Copyrights}

Copyright for this article is retained by the author(s), with first publication rights granted to the journal.

This is an open-access article distributed under the terms and conditions of the Creative Commons Attribution license (http://creativecommons.org/licenses/by/3.0/). 